\title{
Use of Escherichia coli Immobilized on Amberlite XAD-4 as a Solid-Phase Extractor for Metal Preconcentration and Determination by Atomic Absorption Spectrometry
}

\author{
A. Rehber TÜRKER ${ }^{* \dagger}$ and Sitkı BAYTAK** \\ *Department of Chemistry, Gazi University, Faculty of Art and Science, 06500, Ankara, Turkey \\ **Department of Chemistry, Harran University, Faculty of Art and Science, 63100, Şanliurfa, Turkey
}

\begin{abstract}
A sensitive solid-phase extraction technique (SPE) for the enrichment of $\mathrm{Fe}(\mathrm{III}), \mathrm{Co}(\mathrm{II}), \mathrm{Mn}(\mathrm{II})$ and $\mathrm{Cr}$ (III) prior to atomic absorption spectrometric analysis is described. Escherichia coli immobilized on Amberlite XAD-4 was used as a solid-phase extractor. The effects of the $\mathrm{pH}$, amount of solid-phase, eluent type and volume of the sample solution on the recovery of the metal ions were investigated. The effect of diverse ions was also investigated. The recoveries of Fe(III), $\mathrm{Co}$ (II), $\mathrm{Mn}$ (II) and $\mathrm{Cr}$ (III) under the optimum conditions were found to be $99 \pm 2,99 \pm 3,98 \pm 2,98 \pm 3 \%$, respectively, at the $95 \%$ confidence level. The detection limits of the metal ions were found as to be $2.4,3.8,1.3$ and $1.7 \mathrm{ng} \mathrm{ml}^{-1}$ for $\mathrm{Fe}(\mathrm{III}), \mathrm{Co}(\mathrm{II}), \mathrm{Mn}(\mathrm{II})$ and $\mathrm{Cr}(\mathrm{III})$ respectively, by applying a preconcentration factor of 25 . The proposed enrichment method was applied to the determination of analytes in Atatürk Dam water samples, and alloy samples (RSD $<5 \%$ ). The accuracy of the method was verified on certified alloy samples (NBS SRM 85b and NBS SRM 59a). The analytes were determined with a relative error lower than $5 \%$ in water and alloy samples.
\end{abstract}

(Received August 26, 2003; Accepted October 8, 2003)

\section{Introduction}

The increasing environmental pollution by toxic metals has required an accurate and sensitive quantitative metal determination in environmental samples. One of the most important targets of analytical chemist is metal quantification at low concentration levels below $\mathrm{ng} \mathrm{ml}^{-1}$ or $\mathrm{ng} \mathrm{g}^{-1}$. Despite recent advances in instrumental techniques and an increase in the selectivity and sensitivity of analytical techniques, a direct determination of trace amounts of elements occurring in samples is still difficult. There is still a need for the preconcentration and separation of trace elements before their analysis due to their low concentrations and potential interfering matrix constituents in numerous samples, such as water, biological and geological samples.

Various separation and preconcentration techniques have been used for trace metals, such as solvent extraction, ${ }^{1-3}$ coprecipitation, ${ }^{4-6}$ electrodeposition, ${ }^{7}$ ion-exchange, ${ }^{8-10}$ cloud point extraction technique ${ }^{11}$ and solid-phase extraction ${ }^{12}$ (SPE), adsorption on activated carbon, ${ }^{13}$ on dithixone-anchored poly(EGDMA-HEMA) microbeads, ${ }^{14}$ on Amberlite resins ${ }^{15}$ and on sepiolite. ${ }^{16}$

The preconcentration procedures employing a solid phase and applied to atomic spectrometry present some advantageous characteristics, such as simplicity, column applicability and a higher preconcentration factor. There is current interest in the

A part of this manuscript was presented at the 3rd Aegen Analytical Chemistry Days, September 29 - October 3, 2002, Polihnitos, Lesvos, Greece.

$\dagger$ To whom correspondence should be addressed.

E-mail: aturker@gazi.edu.tr development of a new solid-phase extractor of high sorption capacity, selectivity and preconcentration factor.

In recent years, preconcentration by microorganisms, such as yeast, fungi, bacteria and algae, based on solid-phase extraction has been widely used. ${ }^{17,18}$ The use of microorganisms as a biosorbent for metals has many advantages over the other preconcentration methods. Some of them are higher recovery, economical advantages, simplicity and environmental protection. In general, microorganisms selectively adsorb a specific element without preconcentrating the matrix. ${ }^{19}$ Microorganisms have been used as freely suspended cells or as loaded cells on a support. The use of immobilized cell systems on a support has many advantages over the use of freely suspended cells. These include better capability of re-using the biomass, better precision for recovery, easy separation of cells from the reaction mixture, high biomass loadings and minimal clogging in continuous flow systems. Immobilized cell systems can be used in both batch and column experiments.

Bağ et al. ${ }^{20}$ studied E. coli immobilized on sepiolite for the preconcentration of $\mathrm{Cu}, \mathrm{Zn}, \mathrm{Fe}, \mathrm{Ni}$ and $\mathrm{Cd}$. The results indicated that the proposed solid phase is suitable for the preconcentration of analytes from alloys. Gonzalez et al. ${ }^{21}$ proposed the on-line preconcentration of $\mathrm{Cd}(\mathrm{II}), \mathrm{Cr}(\mathrm{III}), \mathrm{Cu}$ (II) and $\mathrm{Pb}(\mathrm{II})$ and the chemical speciation of $\mathrm{Cr}(\mathrm{III})$ and $\mathrm{Cr}(\mathrm{VI})$ using dealginated seaweed biomass. Carrillo et al. ${ }^{22}$ studied the biosorption of $\mathrm{Al}, \mathrm{Co}, \mathrm{Cu}$ and $\mathrm{Fe}$ by brown alga Pilayella littoralis in a flow-injection system. In other studies, algae cells $^{23}$ and bacteria, such as E. coli and $P$. putida, ${ }^{24}$ have been used as biomass. Robles et al. ${ }^{24}$ used two types of living and dead bacteria, E. coli and $P$. putida, to investigate the accumulation of gold. Mahan and Holcombe ${ }^{25}$ studied algaesilica to preconcentrate $\mathrm{Cu}, \mathrm{Cd}, \mathrm{Pb}$ and $\mathrm{Zn}$ in simulated seawater and river-water solutions. Pardo et $a l .{ }^{26}$ investigated 
the accumulation of $\mathrm{Cd}(\mathrm{II}), \mathrm{Cu}(\mathrm{II}), \mathrm{Pb}$ (II) and $\mathrm{Zn}$ (II) at $\mathrm{mg} \mathrm{1}^{-1}$ levels by inactive freeze-dried biomass of Pseudomonas putida.

In previous studies, various materials, such as controlled pore glass (CPG), ${ }^{27}$ silica gel ${ }^{28}$ and sepiolite ${ }^{20}$ have been used as substrates for the immobilization of microorganisms.

In this study, Amberlite XAD-4 resin, which was previously used as an adsorbent, was used as a substrate for the immobilization of E. coli. The main advantage of Amberlite XAD-4 over pore glass, silica and sepiolite is the commercially availability of pure resin having a uniform pore distribution, high surface area, durable and chemically homogeneous structure. The resulting solid-phase extractor was examined for the enrichment of $\mathrm{Fe}(\mathrm{III}), \mathrm{Co}(\mathrm{II}), \mathrm{Mn}$ (II) and $\mathrm{Cr}(\mathrm{III})$ in a column procedure. The optimum enrichment conditions of $\mathrm{Fe}(\mathrm{III})$, $\mathrm{Co}(\mathrm{II}), \mathrm{Mn}(\mathrm{II})$ and $\mathrm{Cr}(\mathrm{III})$ by this solid-phase extractor were determined. Atomic absorption spectrometry was used as a detection technique. The proposed method was applied to the determination of these elements in water and alloy samples. Because Amberlite XAD-4 has been used as an adsorbent in previous studies, some experiments were also performed like using Amberlite XAD-4 alone as a solid phase for a comparison.

\section{Experimental}

\section{Apparatus}

A Philips PU 9285 Model atomic absorption spectrometer equipped with deuterium lamp background correction and an air-acetylene burner was used for the determination of iron, cobalt, manganese and chromium, under the following conditions: wavelength, $248.3 \mathrm{~nm}, 240.7 \mathrm{~nm}, 279.5 \mathrm{~nm}$ and $357.9 \mathrm{~nm}$; spectral bandwidth, $1.0 \mathrm{~nm}, 1.0 \mathrm{~nm}, 1.0 \mathrm{~nm}$ and 1.0 $\mathrm{nm}$; lamp current, $11.2 \mathrm{~mA}, 11.0 \mathrm{~mA}, 9.0 \mathrm{~mA}$ and $12.0 \mathrm{~mA}$; acetylene flow rate, $0.9,1.1,1.0$ and $1.41 \mathrm{~min}^{-1}$ for iron, cobalt, manganese and chromium, respectively. All pH measurements were performed with a JENWAY 3010 Model digital pH meter. Metal sorption studies on the solid-phase extractor were performed using a column of $1 \mathrm{~cm}$ in diameter and $20 \mathrm{~cm}$ in height.

\section{Reagents}

Doubly distilled water and analytical reagent-grade chemicals were used unless otherwise specified. Manganese, cobalt, iron and chromium stock solutions $\left(1000 \mu \mathrm{g} \mathrm{ml}^{-1}\right)$ were prepared by dissolving appropriate amounts of $\mathrm{MnSO}_{4} \cdot \mathrm{H}_{2} \mathrm{O}$ (Merck), $\mathrm{Co}\left(\mathrm{NO}_{3}\right)_{2} \cdot 6 \mathrm{H}_{2} \mathrm{O}$ (Merck), iron powder and $\mathrm{Cr}\left(\mathrm{NO}_{3}\right)_{2} \cdot 9 \mathrm{H}_{2} \mathrm{O}$ (Merck) by an appropriate solvent. Working solutions of the metal ions were prepared by a suitable dilution of a stock solution with doubly distilled water. Amberlite XAD-4 (Sigma Chem. $20-40$ mesh, $780 \mathrm{~m}^{2} \mathrm{~g}^{-1}$ ) was used as a substrate for the immobilization of Escherichia coli.

\section{Preparation of solid-phase extractor}

The bacterium Escherichia coli was maintained, cultivated, grown and prepared as a dry bacterial powder according to a procedure given by Bağ et al. ${ }^{20}$ Commercially available Amberlite XAD-4 was prepared as a substrate by washing successively with methanol, water, $1 \mathrm{~mol} \mathrm{l}^{-1} \mathrm{HCl}$ and water, to remove organic and inorganic contaminants. Then, the immobilization of Escherichia coli on the substrate was performed as follows: $150 \mathrm{mg}$ of dry and dead bacteria powder was mixed with $1 \mathrm{~g}$ of Amberlite XAD-4. The mixture was wetted with $2 \mathrm{ml}$ of doubly distilled water and thoroughly mixed. After mixing, the paste was heated in an oven at about
Table 1 Effect of the type and volume of elution solutions on the recoveries of $\mathrm{Fe}(\mathrm{III}), \mathrm{Co}(\mathrm{II}), \mathrm{Mn}$ (II) and $\mathrm{Cr}$ (III)

\begin{tabular}{|c|c|c|c|c|}
\hline Element & $\begin{array}{l}\text { Type of elution } \\
\text { solution }\end{array}$ & $\begin{array}{c}\text { Volume/ } \\
\mathrm{ml}\end{array}$ & $\begin{array}{c}\text { Concentration/ } \\
\mathrm{mol} \mathrm{l}^{-1}\end{array}$ & $\begin{array}{c}\text { Recovery, }{ }^{\mathrm{a}} \\
\%\end{array}$ \\
\hline \multirow[t]{4}{*}{$\mathrm{Fe}(\mathrm{III})$} & \multirow[t]{2}{*}{$\mathrm{HCl}$} & 5 & 1 & 85 \\
\hline & & 10 & 1 & 99 \\
\hline & \multirow[t]{2}{*}{$\mathrm{HNO}_{3}$} & 5 & 1 & 75 \\
\hline & & 10 & 1 & 82 \\
\hline \multirow[t]{4}{*}{$\mathrm{Co}(\mathrm{II})$} & \multirow[t]{2}{*}{$\mathrm{HCl}$} & 5 & 1 & 88 \\
\hline & & 10 & 1 & 98 \\
\hline & \multirow[t]{2}{*}{$\mathrm{HNO}_{3}$} & 5 & 1 & 74 \\
\hline & & 10 & 1 & 80 \\
\hline \multirow{4}{*}{$\operatorname{Mn}(\mathrm{II})$} & \multirow{2}{*}{$\mathrm{HCl}$} & 5 & 1 & 87 \\
\hline & & 10 & 1 & 98 \\
\hline & \multirow[t]{2}{*}{$\mathrm{HNO}_{3}$} & 5 & 1 & 65 \\
\hline & & 10 & 1 & 72 \\
\hline \multirow[t]{4}{*}{$\mathrm{Cr}(\mathrm{III})$} & $\mathrm{HCl}$ & 10 & 1 & 35 \\
\hline & $\mathrm{HNO}_{3}$ & 10 & 1 & 27 \\
\hline & $\mathrm{HCl}$ (in acetone) & 10 & 1 & 98 \\
\hline & $\mathrm{HNO}_{3}$ (in acetone) & 10 & 1 & 84 \\
\hline
\end{tabular}

a. Mean of three determinations.

$105^{\circ} \mathrm{C}$ for $1 \mathrm{~h}$ to dry the mixture. The wetting and drying step were repeated to maximize the contact between Escherichia coli and Amberlite XAD-4, thereby improving the immobilization efficiency.

\section{Preparation of the column}

First, $0.3 \mathrm{~g}$ of Amberlite XAD-4 loaded with Escherichia coli was packed in a glass column (10 mm i.d. and $200 \mathrm{~mm}$ length). Before use, a $1 \mathrm{~mol} \mathrm{l}^{-1} \mathrm{HCl}$ solution and doubly distilled water were passed through the column in order to condition and clean it. Then, the column was conditioned to the studied $\mathrm{pH}$ by passing an aqueous solution of $\mathrm{HCl}$ or $\mathrm{NH}_{3}$ having the same $\mathrm{pH}$ as that of sample solution through the column, prior to passage of the sample solution.

\section{General enrichment procedure}

An off-line column-SPE procedure was applied for preconcentration. An aliquot of the sample solution $(100 \mathrm{ml})$ containing $50 \mu \mathrm{g}$ of $\mathrm{Fe}(\mathrm{III}), 30 \mu \mathrm{g}$ of $\mathrm{Co}(\mathrm{II}), 30 \mu \mathrm{g}$ of $\mathrm{Mn}(\mathrm{II})$ and $20 \mu \mathrm{g}$ of $\mathrm{Cr}$ (III) was taken and the $\mathrm{pH}$ was adjusted to the optimum value, determined experimentally with hydrochloric acid or ammonia. The resulting solution was passed through the

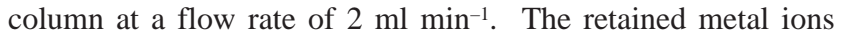
were then eluted from the solid phase with a suitable eluent, determined experimentally (Table 1). The concentration of the metal ions in the eluate was determined by atomic absorption spectrometry. Escherichia coli immobilized on Amberlite XAD-4 was used repeatedly after washing with a $1 \mathrm{~mol} \mathrm{l}^{-1} \mathrm{HCl}$ solution and then distilled water.

The recovery $(R)$ of the metal ions was calculated from the ratio of the concentration found by FAAS to that calculated theoretically.

\section{Dissolution of alloy samples}

The dissolution of ferrosilicon alloy (NBS SRM 59a) was performed according to the procedure adopted by Acar et al. ${ }^{29}$ After $0.3 \mathrm{~g}$ of alloy was taken and the dissolution procedure was applied, the resulting solution was transferred into a $250 \mathrm{ml}$ 


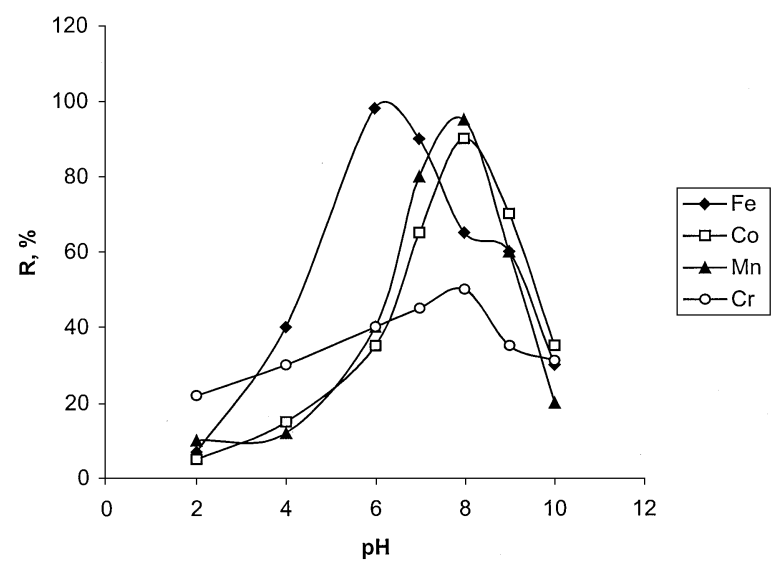

Fig. 1 Effect of the pH on the recoveries of $\mathrm{Fe}(\mathrm{III}), \mathrm{Co}(\mathrm{II}), \mathrm{Mn}(\mathrm{II})$ and $\mathrm{Cr}(\mathrm{III}) . \mathrm{Fe}(\mathrm{III}), 0.5 \mu \mathrm{g} \mathrm{ml}^{-1} ; \mathrm{Co}(\mathrm{II})$ and $\mathrm{Mn}(\mathrm{II}), 0.3 \mu \mathrm{g} \mathrm{ml} l^{-1}$; $\mathrm{Cr}(\mathrm{III}), 0.2 \mu \mathrm{g} \mathrm{ml}^{-1}$; solid-phase, $0.3 \mathrm{~g}$; sample volume, $100 \mathrm{ml}$; flow

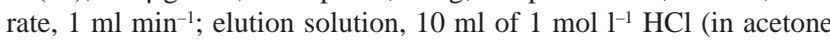
for $\mathrm{Cr}$ ).

volumetric flask and diluted to the mark with doubly distilled water.

Aluminum alloy (NBS SRM 85b) was dissolved as follows: $0.2 \mathrm{~g}$ of aluminum alloy was dissolved in a $250 \mathrm{ml}$ beaker by adding $5 \mathrm{ml}$ of concentrated hydrochloric acid. The solution was heated on a water bath $\left(\sim 80^{\circ} \mathrm{C}\right)$ for $30 \mathrm{~min}$ to complete dissolution. The solution was cooled and transferred to a 100 $\mathrm{ml}$ volumetric flask and diluted to the mark with water. After $0.1 \mathrm{ml}$ of each sample solution was diluted again to reduce the analyte concentration at the working range of the atomic absorption spectrometric method, the matrix concentration was reduced.

For analyzing aluminum foil, a $0.1 \mathrm{~g}$ of aluminum foil was dissolved in $10 \mathrm{ml}$ of $2 \mathrm{~mol} \mathrm{l}^{-1}$ hydrochloric acid and $5 \mathrm{ml}$ of 2 mol $\mathrm{l}^{-1}$ nitric acid in a $50 \mathrm{ml}$ conical flask. The flask was heated on a hot plate $\left(70-80^{\circ} \mathrm{C}\right)$ until the solution became clear. The solution was transferred to a $100 \mathrm{ml}$ volumetric flask with small portions of $0.05 \mathrm{~mol} \mathrm{l}^{-1}$ nitric acid and the volume was made up with $0.05 \mathrm{~mol} \mathrm{l}^{-1}$ nitric acid. The resulting solution was spiked with an appropriate amount of analytes in order to check the accuracy. Spiked and unspiked sample solutions were subjected to the preconcentration and determination procedure.

\section{Results and Discussion}

\section{Effect of the $\mathrm{pH}$}

The $\mathrm{pH}$ of the sample solution plays a crucial role in microbial biosorption. Thus, the retention of the analytes on the column containing Escherichia coli immobilized on Amberlite XAD-4 was studied as a function of the $\mathrm{pH}$. For that purpose, a set of solutions $(100 \mathrm{ml})$ each containing one of the four metal ions at a concentration given in the section of "General enrichment procedure" was taken. The $\mathrm{pH}$ value of the sample solutions was adjusted to a range of $2-10$ with $\mathrm{HCl}$ or $\mathrm{NH}_{3}$. The obtained solutions were passed through the column at a flow rate at about $2 \mathrm{ml} \mathrm{min}^{-1}$. The metal ions were then eluted by an appropriate eluent (Table 1) and determined by FAAS.

In all cases, metal retention by the adsorbent (biomass) increased with increasing $\mathrm{pH}$ and reached a maximum, after which the retention decreased. As can be seen in Fig. 1, the optimum $\mathrm{pH}$ of the sample solution was about 8 for $\mathrm{Mn}(\mathrm{II})$, $\mathrm{Co}(\mathrm{II})$ and $\mathrm{Cr}(\mathrm{III})$, and about 6 for $\mathrm{Fe}(\mathrm{III})$. These results show

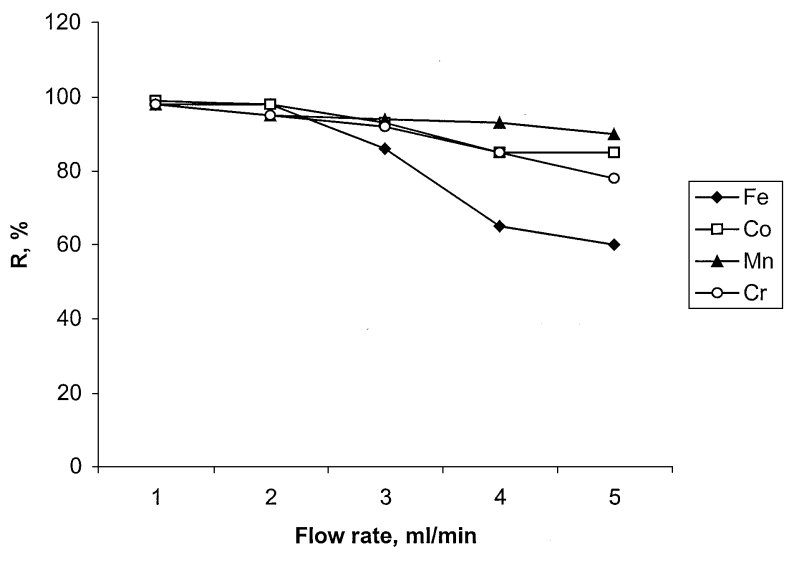

Fig. 2 Effect of the flow rate of the sample solutions on the recoveries of $\mathrm{Fe}(\mathrm{III}), \mathrm{Co}(\mathrm{II}), \mathrm{Mn}(\mathrm{II})$ and $\mathrm{Cr}(\mathrm{III}) . \mathrm{Fe}(\mathrm{III}), 0.5 \mu \mathrm{g} \mathrm{m}^{-1}$; $\mathrm{Co}(\mathrm{II})$ and $\mathrm{Mn}(\mathrm{II}), 0.3 \mu \mathrm{g} \mathrm{ml}^{-1}$; $\mathrm{Cr}(\mathrm{III}), 0.2 \mu \mathrm{g} \mathrm{m}^{-1}$; solid-phase, 0.3 $\mathrm{g}$; sample volume, $100 \mathrm{ml}$; elution solution, $10 \mathrm{ml}$ of $1 \mathrm{~mol} \mathrm{l}^{-1} \mathrm{HCl}$ (in acetone for $\mathrm{Cr}$ ).

that the adsorption could be attributed to ionic attraction between the metal ions and the biomass. The microbial cell products, such as metabolites, polysaccharides, and the cell-wall constituents, are effective in metal accumulating. There are many binding sites on the cell wall of microorganisms, and the binding sites of microorganisms have a diversity property. When the cell surface becomes more positively charged, the attraction between metal ions and the functional groups on cell wall at low $\mathrm{pH}$ values is reduced. When more negatively charged, the attraction at higher $\mathrm{pH}$ values is increased until a maximum is reached at around $\mathrm{pH} 7$. For $\mathrm{pH}$ values higher than the optimum values, the retention decreases again because of the formation of hydroxylated complexes of the metal. ${ }^{26}$

\section{Effect of the amount of solid phase (bed height)}

The retention of the analytes was examined in relation to the amount of solid phase, which was varied from $100 \mathrm{mg}$ to 400 $\mathrm{mg}$. It was found that the recoveries of $\mathrm{Fe}(\mathrm{III}), \mathrm{Co}(\mathrm{II}), \mathrm{Cr}$ (III) and $\mathrm{Mn}$ (II) were gradually increased up to 200, 200, 200 and $300 \mathrm{mg}$ of the solid phase, respectively. Therefore, $200 \mathrm{mg}$ of the solid phase was used for $\mathrm{Fe}(\mathrm{III}), \mathrm{Co}(\mathrm{II})$ and $\mathrm{Cr}(\mathrm{III})$, and 300 $\mathrm{mg}$ of the solid phase was used for $\mathrm{Mn}(\mathrm{II})$ in subsequent experiments.

\section{Effect of the type and volume of elution solutions}

Optimization of the elution conditions was performed in order to obtain the maximum recovery with the minimal concentration and volume of the elution solution. The different concentrations of nitric acid and hydrochloric acid in water and in acetone were tested to remove the bound metal ions from the biomass. As can be seen from Table 1, $10 \mathrm{ml}$ of $1 \mathrm{~mol} \mathrm{l}^{-1} \mathrm{HCl}$ solution was found to be satisfactory (recovery $>95 \%$ ) for $\mathrm{Fe}(\mathrm{III}), \mathrm{Co}$ (II) and $\mathrm{Mn}$ (II), and $10 \mathrm{~mL}$ of $1 \mathrm{~mol} \mathrm{l}^{-1} \mathrm{HCl}$ (in acetone) was for $\mathrm{Cr}(\mathrm{III})$.

\section{Effect of the flow rates of sample solutions}

The retention of an element on an adsorbent also depends on the flow rate of the sample solution. Thus, the effect of the flow rate of the sample solution on the recovery of the analytes was investigated under the optimum conditions $(\mathrm{pH}$, eluent type, etc.). The sample solution was passed through the column with the flow rates adjusted in a range of $1-5 \mathrm{ml} \mathrm{min}^{-1}$ by gravity. As can be seen in Fig. 2, at flow rates greater than $2 \mathrm{ml} \mathrm{min}{ }^{-1}$ 


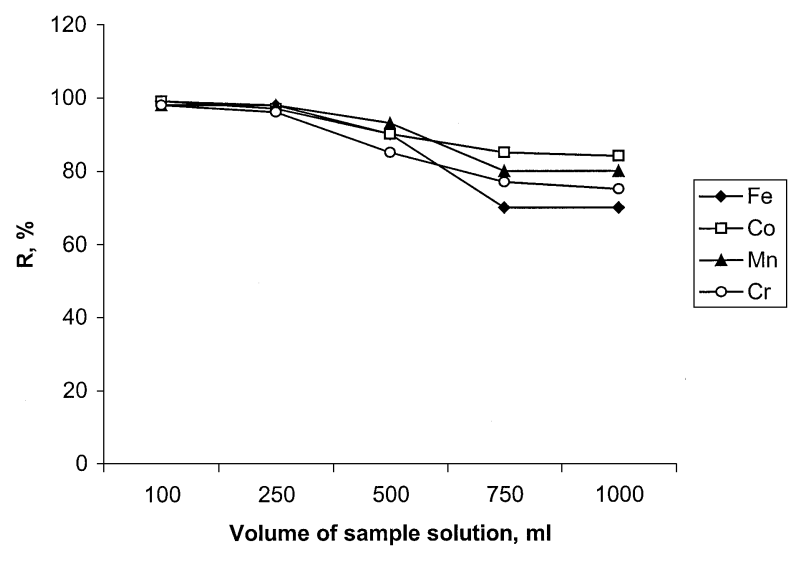

Fig. 3 Effect of the volume of the sample solution on the recoveries of $\mathrm{Fe}(\mathrm{III}), \mathrm{Co}(\mathrm{II}), \mathrm{Mn}(\mathrm{II})$ and $\mathrm{Cr}(\mathrm{III})$. $\mathrm{Fe}(\mathrm{III}), 0.5 \mu \mathrm{g} \mathrm{ml}^{-1}$; $\mathrm{Co}$ (II) and $\mathrm{Mn}$ (II), $0.3 \mu \mathrm{g} \mathrm{ml}{ }^{-1}$; $\mathrm{Cr}(\mathrm{III}), 0.2 \mu \mathrm{g} \mathrm{ml}^{-1}$; $\mathrm{pH}, 6$ for Fe and 8 for $\mathrm{Co}$ and $\mathrm{Mn}$; solid-phase, $0.2 \mathrm{~g}$ for $\mathrm{Fe}$ and $\mathrm{Co}, 0.3 \mathrm{~g}$ for $\mathrm{Mn}$; elution solution, $10 \mathrm{ml}$ of $1 \mathrm{~mol} \mathrm{l}^{-1} \mathrm{HCl}$ (in acetone for $\mathrm{Cr}$ ).

there was a decrease in the recovery of all analytes. The reason for this decrease is probably insufficient contact of the metal ions and the adsorbent to reach equilibrium. Therefore, as the flow rate of the sample solution, $2 \mathrm{ml} \mathrm{min}{ }^{-1}$ was adapted in subsequent experiments. The flow rate of the elution solution was $1 \mathrm{ml} \mathrm{min}{ }^{-1}$.

\section{Effect of the volume of the sample solution}

In order to determine the volume of an applicable sample solution (or minimum analyte concentration), the effect of changes in the volume of the sample solution passed through the column on the retention of the analytes was also investigated. First, 100, 250, 500, 750, and $1000 \mathrm{ml}$ of sample solutions containing fixed amounts of analytes ( $50 \mu \mathrm{g}$ of $\mathrm{Fe}(\mathrm{III}), 30 \mu \mathrm{g}$ of $\mathrm{Co}(\mathrm{II}), 30 \mu \mathrm{g}$ of $\mathrm{Mn}(\mathrm{II})$ and $20 \mu \mathrm{g}$ of $\mathrm{Cr}(\mathrm{III}))$ which corresponds to $0.5,0.2,0.1,0.066,0.05 \mu \mathrm{ml}^{-1} \mathrm{Fe}(\mathrm{III}), 0.30,0.12,0.06$, 0.04, $0.03 \mu \mathrm{g} \mathrm{ml}^{-1} \mathrm{Mn}(\mathrm{II})$ and $\mathrm{Co}(\mathrm{II})$, and 0.2, 0.08, 0.04, 0.027, $0.02 \mu \mathrm{g} \mathrm{ml}^{-1} \mathrm{Cr}$ (III) were passed through the column under the optimum conditions ( $\mathrm{pH}$, eluent type, flow rate, etc.). It was then found that all analytes could be recovered quantitatively (> 95\%) up to $250 \mathrm{ml}$ of the sample solution. At higher sample volumes, the recoveries gradually decreased with increasing volume of the sample (Fig. 3). In this study, because of the elution volume was $10 \mathrm{ml}$, a 25 -fold preconcentration could be obtained for all of the analytes studied. It can be concluded that iron, cobalt, manganese and chromium can be determined at concentrations of $0.2 \mu \mathrm{g} \mathrm{ml}^{-1}, 0.12 \mu \mathrm{g} \mathrm{ml}^{-1}, 0.12 \mu \mathrm{g} \mathrm{ml}^{-1}$, and $0.08 \mu \mathrm{g} \mathrm{ml}^{-1}$, respectively. These concentrations can not be determined directly by atomic absorption spectrometry with sufficient accuracy.

\section{Effect of interfering ions}

In order to investigate the effect of the interfering ions, especially alkaline and alkaline earth elements, the main components of the alloys to be analyzed were added to a synthetic sample solution containing analytes. The recoveries of $\mathrm{Fe}(\mathrm{III}), \mathrm{Co}(\mathrm{II}), \mathrm{Mn}$ (II) and $\mathrm{Cr}$ (III) were also examined when they existed together in the same medium. The concentrations of iron, cobalt, manganese and chromium were fixed at $0.5 \mu \mathrm{g}$ $\mathrm{ml}^{-1}, 0.3 \mu \mathrm{g} \mathrm{ml}^{-1}, 0.3 \mu \mathrm{g} \mathrm{ml}^{-1}, 0.2 \mu \mathrm{g} \mathrm{ml}^{-1}$, respectively, and the concentration of interfering metal ions were adjusted over the range of $0.5-1000 \mu \mathrm{g} \mathrm{ml}^{-1}$. Other ions present in the solution
Table 2 Effect of other ions on the recoveries of Fe(III), $\mathrm{Co}(\mathrm{II}), \mathrm{Mn}(\mathrm{II})$ and $\mathrm{Cr}(\mathrm{III})^{\mathrm{a}}$

\begin{tabular}{|c|c|c|c|c|c|}
\hline \multirow{2}{*}{$\begin{array}{l}\text { Interfering } \\
\quad \text { ion }\end{array}$} & \multirow{2}{*}{$\begin{array}{l}\text { Concentration/ } \\
\mu \mathrm{g} \mathrm{ml}^{-1}\end{array}$} & \multicolumn{4}{|c|}{ Recovery, \% } \\
\hline & & $\mathrm{Fe}(\mathrm{III})$ & $\mathrm{Co}$ (II) & $\mathrm{Mn}(\mathrm{II})$ & $\mathrm{Cr}(\mathrm{III})$ \\
\hline \multirow[t]{6}{*}{$\mathrm{Na}^{+}$} & - & 99 & 98 & 98 & 98 \\
\hline & 25 & 99 & 98 & 98 & 98 \\
\hline & 50 & 99 & 98 & 98 & 97 \\
\hline & 100 & 99 & - & 98 & 97 \\
\hline & 500 & 98 & 98 & 90 & 96 \\
\hline & 1000 & 95 & 97 & 85 & 95 \\
\hline \multirow[t]{8}{*}{$\mathrm{K}^{+}$} & - & 99 & 98 & 98 & 98 \\
\hline & 20 & 99 & - & 98 & 97 \\
\hline & 25 & - & 98 & - & 97 \\
\hline & 30 & - & - & 98 & 97 \\
\hline & 50 & 99 & 98 & 98 & 97 \\
\hline & 100 & 98 & 98 & 98 & 96 \\
\hline & 250 & - & 98 & 95 & 96 \\
\hline & 500 & 95 & - & 85 & 95 \\
\hline \multirow[t]{4}{*}{$\mathrm{Ca}^{2+}$} & - & 99 & 98 & 98 & 98 \\
\hline & 10 & - & 96 & 98 & 97 \\
\hline & 20 & 95 & 80 & 83 & 96 \\
\hline & 50 & 85 & 65 & - & 89 \\
\hline \multirow[t]{6}{*}{$\mathrm{Mg}^{2+}$} & - & 99 & 98 & 98 & 98 \\
\hline & 0.5 & 99 & 98 & 98 & 98 \\
\hline & 1 & 99 & - & 95 & 97 \\
\hline & 2.5 & 95 & 98 & 80 & 96 \\
\hline & 5 & 87 & 98 & 60 & 90 \\
\hline & 10 & - & 82 & - & - \\
\hline \multirow[t]{3}{*}{$\mathrm{Al}^{3+}$} & - & & 98 & 98 & 98 \\
\hline & 250 & & 98 & 97 & 97 \\
\hline & 500 & & 96 & 95 & 97 \\
\hline \multirow[t]{3}{*}{$\mathrm{Fe}^{3+}$} & - & - & 97 & 98 & 98 \\
\hline & 15 & - & 96 & 97 & - \\
\hline & 30 & - & 95 & 95 & - \\
\hline
\end{tabular}

a. Concentrations of $\mathrm{Fe}(\mathrm{III}), \mathrm{Co}(\mathrm{II}), \mathrm{Mn}(\mathrm{II})$ and $\mathrm{Cr}(\mathrm{III})$ are $0.5,0.3$, $0.3,0.2 \mu \mathrm{g} \mathrm{ml}^{-1}$, respectively.

generally have a negative impact on the metal retention because of the competition between ions. The results were given in Table 2. As can be seen in the table, $\mathrm{Na}$ and $\mathrm{K}$ did not interfere in the determination of analytes up to $500 \mu \mathrm{g} \mathrm{ml}^{-1}$. However, $\mathrm{Ca}$ and $\mathrm{Mg}$ interfered in the determination when they existed above $10 \mu \mathrm{g} \mathrm{ml}^{-1}$ and $2.5 \mu \mathrm{g} \mathrm{ml}^{-1}$, respectively.

\section{Effect of column reuse}

To test the long-term stability of the adsorbent, the column was subjected to successive adsorption and desorption cycles by passing $100 \mathrm{ml}$ of metal solutions through it. The procedure was carried out five times in a day and the next five runs were made one day later, and so on. The stability and potential recyclability of the column were assessed by monitoring the change in the recoveries of the analytes. For all of the analytes studied, after 15 runs a decrease appeared in the recoveries. The column seems to have been relatively stable up to 15 runs.

\section{Capacity studies}

To evaluate the amount of metal adsorbed onto the coordination sites of the immobilized E. coli, the breakthrough capacity was studied. The breakthrough capacity was evaluated from the breakthrough curve plot by a method given by Bağ et $a l .{ }^{30}$ The breakthrough capacities were found as to be 21 and 28 $\mu \mathrm{mol} \mathrm{g}{ }^{-1}$ for $\mathrm{Mn}(\mathrm{II})$ and $\mathrm{Co}(\mathrm{II})$ when using E. coli, and 15 and $20 \mu \mathrm{mol} \mathrm{g}{ }^{-1}$ without using $E$. coli, respectively. As can be seen from the results, the capacity of $E$. coli immobilized on 
Table 3 Recovery of the analytes and repeatability of the method

\begin{tabular}{lccccc}
\hline \multirow{2}{*}{ Element } & \multicolumn{2}{c}{ With microorganism } & & \multicolumn{2}{c}{ Without microorganism } \\
\cline { 2 - 3 } \cline { 6 - 6 } & $\% R \pm t s^{\mathrm{a}} \sqrt{N}$ & $\mathrm{RSD}^{\mathrm{b}}, \%$ & & $\%$ $\pm t s / \sqrt{N}$ & $\mathrm{RSD}, \%$ \\
\hline $\mathrm{Fe}(\mathrm{III})$ & $99 \pm 2$ & 1.6 & & $35 \pm 2$ & 4.6 \\
$\mathrm{Co}(\mathrm{II})$ & $99 \pm 3$ & 2.4 & & $40 \pm 2$ & 4.0 \\
$\mathrm{Mn}(\mathrm{II})$ & $98 \pm 2$ & 1.6 & & $68 \pm 3$ & 2.4 \\
$\mathrm{Cr}(\mathrm{III})$ & $98 \pm 3$ & 2.0 & & $35 \pm 2$ & 4.6 \\
\hline
\end{tabular}

a. Uncertainity at $95 \%$ confidence limit $(N=5)$.

b. Relative standard deviation.

Table 4 Determinations of $\mathrm{Fe}(\mathrm{III}), \mathrm{Co}(\mathrm{II}), \mathrm{Mn}(\mathrm{II})$ and $\mathrm{Cr}(\mathrm{III})$ in alloys

\begin{tabular}{lllcc}
\hline \multirow{2}{*}{ Sample } & Element & $\begin{array}{c}\text { Certified, } \\
(\mathrm{m} / \mathrm{m})\end{array}$ & $\begin{array}{c}\text { Found, } \%(\mathrm{~m} / \mathrm{m}) \\
(x \pm t s / \sqrt{N})\end{array}$ & $\begin{array}{c}\text { Error, } \\
\%\end{array}$ \\
\hline \multirow{2}{*}{ NBS SRM 85b } & $\mathrm{Fe}$ & 0.24 & $0.23 \pm 0.02$ & -4 \\
& $\mathrm{Mn}$ & 0.61 & $0.58 \pm 0.03$ & -5 \\
& $\mathrm{Cr}$ & 0.211 & $0.20 \pm 0.03$ & -5 \\
& $\mathrm{Co}^{\mathrm{c}}$ & 0.50 & $0.48 \pm 0.02$ & -4 \\
NBS SRM 59a & $\mathrm{Mn}$ & 0.75 & $0.74 \pm 0.05$ & -2 \\
& $\mathrm{Cr}$ & 0.080 & $0.076 \pm 0.010$ & -5 \\
& $\mathrm{Co}^{\mathrm{c}}$ & 0.32 & $0.31 \pm 0.02$ & -4 \\
\hline
\end{tabular}

a. The composition of the aluminum based alloy (NBS SRM 85b) was Al 93.097, Mn 0.61, Si 0.18, Cu 3.99, Ni 0.084, Cr 0.211, V 0.006, Ti 0.022, Ga 0.019, Fe 0.24, Pb 0.021, Mg 1.49 and $\mathrm{Zn}$ $0.030 \%(\mathrm{~m} / \mathrm{m})$. The composition of the ferrosilicon based alloy (NBS SRM 59a) was Al 0.35, Mn 0.75, Si 48.10, Cu 0.052, Ni 0.033, $\mathrm{Cr} 0.080$, Fe 50.05, C 0.046, S 0.002, P 0.016, Ca 0.042 and B $0.058 \%(\mathrm{~m} / \mathrm{m})$.

b. Mean of five determinations at $95 \%$ confidence level.

c. Co was added to the solutions of NBS SRM 59a and $85 \mathrm{~b}$.

Amberlite XAD-4 was higher than that Amberlite XAD-4 alone for both of the ions studied. The capacity of the column for $\mathrm{Fe}$ (III) and $\mathrm{Cr}$ (III) was not studied, because precipitation of $\mathrm{Fe}(\mathrm{III})$ and $\mathrm{Cr}$ (III) occurred at higher concentration levels over the studied $\mathrm{pH}$.

\section{Analytical features}

To determine the precision of the method, successive retention and elution cycles were performed with $100 \mathrm{ml}$ of a sample solution containing $50 \mu \mathrm{g}$ of $\mathrm{Fe}(\mathrm{III}), 30 \mu \mathrm{g}$ of $\mathrm{Mn}(\mathrm{II})$ and $\mathrm{Co}(\mathrm{II})$, and $20 \mu \mathrm{g}$ of $\mathrm{Cr}(\mathrm{III})$ under the optimum conditions, mentioned above. As can be seen from Table 3, the recoveries of Fe(III), $\mathrm{Co}(\mathrm{II}), \mathrm{Mn}(\mathrm{II})$ and $\mathrm{Cr}(\mathrm{III})$ were quantitative (> 95\%) and the precision of the method was very good (RSD < 3\%) for Escherichia coli immobilized on Amberlite XAD-4. The results found by using Amberlite XAD-4 alone were also given for a comparison. As can be seen from the table, the recoveries of the analytes were very low when using Amberlite XAD-4 alone as an adsorbent. To increase the recovery of the elements by using Amberlite XAD-4, it is usually necessary to use a chelating agent prior to the column procedure. ${ }^{14}$ By using Escherichia coli immobilized on Amberlite XAD-4, there is no need to use a chelating agent.

The linear calibration ranges for measurements under the optimum conditions were $1.0-8.0 \mu \mathrm{g} \mathrm{ml}^{-1}$ for $\mathrm{Fe}(\mathrm{III}), 0.5-5.0$ $\mu \mathrm{g} \mathrm{ml}^{-1}$ for $\mathrm{Co}(\mathrm{II}), \mathrm{Mn}(\mathrm{II})$ and $\mathrm{Cr}(\mathrm{III})$.

To determine the detection limit, $50 \mathrm{ml}$ of a blank solution
Table 5 Determinations of $\mathrm{Fe}(\mathrm{III}), \mathrm{Co}(\mathrm{II}), \mathrm{Mn}(\mathrm{II})$ and $\mathrm{Cr}(\mathrm{III})$ in Atatürk Dam water (sample volume $250 \mathrm{ml}$ )

\begin{tabular}{cccc}
\hline Element & Added/ $\mu \mathrm{g} \mathrm{l}^{-1}$ & $\begin{array}{c}\text { Found }^{\mathrm{a}} / \mu \mathrm{g} \mathrm{l}^{-1} \\
(x \pm t s / \sqrt{N})\end{array}$ & Error, \% \\
\hline $\mathrm{Fe}(\mathrm{III})$ & - & $38.0 \pm 0.7$ & - \\
$\mathrm{Co}(\mathrm{II})$ & 100 & $135 \pm 2$ & -2 \\
$\mathrm{Mn}(\mathrm{II})$ & - & $24.0 \pm 0.9$ & - \\
$\mathrm{Cr}(\mathrm{III})$ & - & $63 \pm 1$ & -2 \\
& 40 & $15 \pm 1$ & - \\
& - & $52 \pm 1$ & -5 \\
\hline
\end{tabular}

a. Mean of five determinations at $95 \%$ confidence level.

was passed through the column and retained metals were eluted by $50 \mathrm{ml}$ of the elution solution mentioned above. The detection limits based on three-times the standard deviation of the blank solution were found to be $60,95,33$ and $43 \mathrm{ng} \mathrm{ml}^{-1}$ for $\mathrm{Fe}(\mathrm{III}), \mathrm{Co}(\mathrm{II}), \mathrm{Mn}(\mathrm{II})$ and $\mathrm{Cr}(\mathrm{III})(N=20)$, respectively. It may be concluded that by applying a preconcentration factor ${ }^{31}$ of 25 for the all analytes, 2.4, 3.8, 1.3 and $1.7 \mathrm{ng} \mathrm{ml}^{-1}$ detection limit for $\mathrm{Fe}(\mathrm{III}), \mathrm{Co}(\mathrm{II}), \mathrm{Mn}(\mathrm{II})$ and $\mathrm{Cr}(\mathrm{III})$, respectively, could be obtained.

To demonstrate the validity and accuracy of the proposed enrichment and determination method, standard reference materials of some alloys have been analyzed. The analytes in the diluted solution of alloys were preconcentrated and determined five times. The results are summarized in Table 4. As can be seen from Table 4, the accuracy of the method was very satisfactory; the percent relative error was lower than $5 \%$.

\section{Application}

To evaluate the applicability of the proposed preconcentration and determination method, aluminum foil and water samples were analyzed as real samples. $\mathrm{Co}(\mathrm{II}), \mathrm{Mn}(\mathrm{II}), \mathrm{Fe}(\mathrm{III})$ and $\mathrm{Cr}$ (III) were determined in a water sample collected from Atatürk Dam and in aluminum foil used for food protection. A water sample was filtered through a MFS membrane filter (pore size $0.45 \mu \mathrm{m}$ ) and analyzed as soon as possible after sampling. A $250 \mathrm{ml}$ sample was adjusted to the optimum $\mathrm{pH}$ and subjected to the recommended column procedure for the preconcentration and determination of metal ions. The water sample was also spiked with the analytes to test the accuracy of the method. The results reported in Table 5, with a confidence interval for the 95\% confidence level, show the applicability of the proposed method to water analysis.

Spiked and unspiked solutions of aluminum foil were subjected to the preconcentration and determination procedure described above. The results are given in Table 6 . The accuracy of the results was quite satisfactory. The relative error was about $5 \%$.

\section{Conclusion}

The proposed SPE enrichment procedure described in this paper provides a simple, sensitive, precise, reliable and accurate technique for the preconcentration of $\mathrm{Fe}(\mathrm{III}), \mathrm{Co}(\mathrm{II}), \mathrm{Mn}$ (II) and $\mathrm{Cr}(\mathrm{III})$. The recoveries of all four metal ions were nearly quantitative $(>95 \%)$. The relative standard deviations for five experiments were $<5 \%$. It can also be concluded that the use of microorganism increased the retention of the analytes with 
Table 6 Determinations of $\mathrm{Fe}(\mathrm{III}), \mathrm{Co}(\mathrm{II}), \mathrm{Mn}(\mathrm{II})$ and $\mathrm{Cr}(\mathrm{III})$ in aluminum foil

\begin{tabular}{cccc}
\hline Element & Added $/ \mu \mathrm{g} \mathrm{g}^{-1}$ & $\begin{array}{c}\text { Found } / \mu \mathrm{g} \mathrm{g}^{-1} \\
\left(x \pm s^{\mathrm{a}}\right)\end{array}$ & Error, \% \\
\hline $\mathrm{Fe}(\mathrm{III})$ & - & $5100 \pm 200$ & - \\
& 10000 & $14600 \pm 500$ & -3 \\
$\mathrm{Co}(\mathrm{II})$ & - & - & - \\
& 200 & $190 \pm 4$ & -5 \\
$\mathrm{Mn}$ (II) & - & $54.6 \pm 0.6$ & - \\
& 100 & $150 \pm 1$ & -3 \\
$\mathrm{Cr}(\mathrm{III})$ & - & $\mathrm{ND}^{\mathrm{b}}$ & - \\
& 100 & $95 \pm 3$ & -5 \\
\hline
\end{tabular}

a. Standard deviation $(N=5)$.

b. ND: Not detected.

respect to Amberlite XAD-4 alone. The analytes could be preconcentrated directly by using the proposed method without using any chelating or complexing agent. The preconcentration technique used in this work is also cheap. Only $0.3 \mathrm{~g}$ of adsorbent is needed, and repeated use is possible. The main disadvantage of the proposed method is the duration time of the preconcentration step. The duration time is about $2 \mathrm{~h}$ for a 250 ml sample solution.

This technique could be combined with other methods of analysis, such as ICP-AES, ICP-MS and electroanalytical methods, and used as an on-line preconcentration system.

\section{Acknowledgements}

The support of Harran University Research Fund is gratefully acknowledged.

\section{References}

1. B. Holynska, B. Ostachwicz, and D. Wegrzynek, Spectrochim. Acta, 1996, 51B, 769.

2. D. Kara and M. Alkan, Talanta, 2001, 55(2), 415.

3. I. Kojima and M. Katsuzaki, Anal. Sci., 1997, 13, 1021.

4. S. J. J. Tsai, C. C. Jan, and L. L. Chang, Spectrochim. Acta, 1994, 49B, 773.

5. S. Kagaya, M. Saiki, Z. A. Malek, Y. Araki, and K. Hasegawa, Fresenius J. Anal. Chem., 2001, 371, 391.

6. D. Atanassova, V. Stefanova, and E. Russeva, Talanta, 1998, 47, 1237.
7. A. Ritschel, P. Wobrauschek, E. Chinea, F. Grass, and Ch. Fabjan, Spectrochim. Acta, 1999, 54B, 1449.

8. G. H. Tao and Z. L. Fang, Fresenius J. Anal. Chem., 1998, $360,156$.

9. R. M. Cespon-Romero, M. C. Yebra-Biurrun, and M. P. Bermejo-Barrera, Anal. Chim. Acta, 1996, 327, 37.

10. A. Cuesta, J. L. Todoli, and A. Canals, Spectrochim. Acta, 1996, 51B, 1791.

11. J. L. Manzoori and G. Karim-Nezhad, Anal. Sci., 2003, 19, 579.

12. H. Bă̆, A. R. Türker, R. Coşkun, M. Saçak, and M. Yiğitoğlu, Spectrochim. Acta, 2000, 55B, 1101.

13. L. Elçi and M. Doğan, Fresenius Z. Anal. Chem., 1988, $330,610$.

14. B. Salih, R. Say, A. Denizli, Ö. Genç, and E. Pişkin, Anal. Chim. Acta, 1998, 371, 177.

15. L. Elçi, M. Soylak, and M. Doğan, Fresenius J. Anal. Chem., 1992, 342, 175.

16. A. R. Türker, H. Bağ, and B. Erdoğan, Fresenius J. Anal. Chem., 1997, 357, 351.

17. H. A. M. Elmahadi and G. M. Greenway, J. Anal. At. Spectrom., 1991, 6, 643.

18. H. Bağ, A. R. Türker, M. Lale, and A. Tunçeli, Talanta, 2000, 51,895 .

19. R. H. Crist, K. Oberhaser, N. Shank, and M. Nguyen, Environ. Sci. Technol., 1981, 15, 1212.

20. H. Bağ, A. R. Türker, and M. Lale, Talanta, 2000, 51, 1035.

21. M. E. Romero-Gonzalez, C. J. Williams, and P. H. D. Gardiner, J. Anal. At. Spectrom., 2000, 15, 1009.

22. E. N. V. M. Carrilho, J. A. Nobrega, and T. R. Gilbert, Talanta, 2003, 60, 1131.

23. L. C. Robles and A. J. Aller, Quim. Anal., 1996, 15, 21.

24. L. C. Robles, C. Garcia-Olalla, and A. J. Aller, J. Anal. At. Spectrom., 1993, 8, 1015.

25. C. A. Mahan and J. A. Holcombe, Spectrochim. Acta, 1992 $47 B, 1483$.

26. R. Pardo, M. Herguedas, E. Barrado, and M. Vega, Anal. Bioanal. Chem., 2003, 376, 32.

27. A. Maquieira, H. A. M. Elmahadi, and R. Puchades, Anal. Chem., 1994, 66, 1462.

28. B. Godlewska-Zylkiewicz, Spectrochim. Acta, 2003, 58B, 1531.

29. O. Acar, A. R. Türker, and Z. Kılıç, Fresenius J. Anal. Chem., 1997, 357, 656.

30. H. Bağ, M. Lale, and A. R. Türker, Talanta, 1998, 47, 689.

31. A. C. Sahayam, Anal. Bioanal. Chem., 2002, 372, 840. 